\title{
OS MODOS DE PRESENÇA NA ERA PANDÊMICA: REFLEXÕES SOBRE OS REGIMES DE VISIBILIDADE NAS LIVES
}

\author{
Modes of presence in the pandemic era: reflections on visibility regiments in lives
}

Modos de presencia en la era pandémica: reflexiones sobre los regimientos de visibilidad en las vidas

Received: november/2020

Accepted: december $/ 2020$

Available online: december/2020

Fabiana Tavolaro Maiorino, Doutora em Educação pela Universidade de São Paulo, Brasil. E-mail: ftmaiorino@gmail.com

Resumo: O presente artigo objetivou contextualizar inicialmente a pandemia provocada pela disseminação do Coronavírus, como um sintoma sócio cultural, provindo de uma crise do modelo raciocêntrico desde a modernidade. Para isso usou de uma visão caleidoscópica, trazendo o olhar de Heidegger, Deleuze, Žižek, Agamben, entre outros, para tipificar essa crise do modelo neoliberal e mundializado do capital. Num segundo momento, focou-se, especificamente, a compreensão do fenômeno das lives na plataforma do Instagram, como uma possível forma de sociabilidade ampliada da cibercultura. Analisada sob o viés da Semiótica Discursiva e fenomenológica de Eric Landowski (2002), tipificou-se essa relação nas lives sob um forte regime de visibilidade, nominado por escópico. Percebeu-se ainda, que esse tipo de contrato intersubjetivo é pautado pelo valor da hipervisibilidade. Apesar da sua potencialidade político comunitário, esse espaço pode aprisionar a expressão das rostidades em imagens clichês, empobrecendo esse campo comunicacional sob a estética massiva e publicitária. Apontamos, portanto, a importância do diálogo e uma nova forma de povoar o ciberespaço.

RBPPD/BRJPD | Vol. 2 | n. 4 | p. 4-23, 2020. 
Palavras-chave: Pandemia, Cibercultura, Lives, Rostidades, Visibilidade, Semiótica.

\begin{abstract}
This article aimed to initially contextualize the pandemic caused by the spread of the coronavirus, as a socio-cultural symptom, arising from a crisis of the raciocentric model since modernity. For this he used a kaleidoscopic view, bringing the eyes of Heidegger, Deleuze, Žižek, Agamben, among others, to typify this crisis of the neoliberal and globalized model of capital. In a second step, the focus was specifically on understanding the phenomenon of lives on the Instagram platform, as a possible form of increased sociability in cyberculture. Analyzed from the perspective of Eric Landowski's Discursive and Phenomenological Semiotics (2002), this relationship was typified in lives under a strong visibility regime, named scopic. It was also noticed that this type of intersubjective contract is based on the value of hypervisibility. Despite its community political potential, this space can imprison the expression of rostities in cliché images, impoverishing this communicational field under massive and advertising aesthetics. We therefore point out the importance of dialogue and a new way of populating cyberspace.
\end{abstract}

Keywords: Pandemic, Cyberculture, Lives, Rostities, Visibility, Semiotics.

Resumen: Este artículo tuvo como objetivo contextualizar inicialmente la pandemia provocada por la propagación del virus coronavirus, como síntoma sociocultural, derivado de una crisis del modelo raciocéntrico desde la modernidad. Para ello utilizó una mirada caleidoscópica, acercando la mirada de Heidegger, Deleuze, Žižek, Agamben, entre otros, para tipificar esta crisis del modelo neoliberal y globalizado de capital. En un segundo paso, la atención se centró específicamente en comprender el fenómeno de las vidas en la plataforma Instagram, como una posible forma de mayor sociabilidad en la cibercultura. Analizada desde la perspectiva de Semiótica discursiva y fenomenológica de Eric Landowski (2002), esta relación se tipificó en vidas bajo un fuerte régimen de visibilidad, denominado escópico. También se notó que este tipo de contrato intersubjetivo se basa en el valor de la hipervisibilidad. A pesar de su potencial político comunitario, este espacio puede aprisionar la expresión de rostidades en imágenes cliché, empobreciendo este campo comunicacional bajo una estética masiva y publicitaria. Por ello, señalamos la importancia del diálogo y una nueva forma de poblar el ciberespacio.

Palabras clave: Pandemia, Cibercultura, Vidas, Rostidades, Visibilidad, Semiótica.

\title{
INTRODUÇÃO
}

Esse artigo destinou-se a pensar como os sujeitos do contemporâneo tem ensaiado regimes de comunicação sob a égide do isolamento social no contexto da pandemia mundial do Covid 19, no ano de 2020. Enfocando, principalmente, o mostrar-se pelo fenômeno das lives no Instagram. Para realizar essa reflexão analítica, optou-se em contextualizar o momento que passamos, com contribuições de Žižek (2020), Heidegger (2010) e Deleuze (2013, 2010), entre outros. Num segundo momento, voltamo-nos ao manejo conceitual da Semiótica pós estruturalista e

RBPPD/BRJPD | Vol. 2 | n. 4 | p. 4-23, 2020. 
fenomenológica de Eric Landowski (2002, 1992), assim como o conceito chave de Rostidades de Deleuze e Guattari (2012), para polemizar como os sujeitos têm se mostrado e fundado um regime de visibilidade através das lives na pandemia.

Para tal intento, fez-se necessário contextualizar inicialmente o cenário sócio cultural desse panorama, que tem mobilizado globalmente diferentes continentes geopolíticos, que se encontram com medidas diferenciadas de isolamento social pelo alastramento vertiginoso do coronavírus. Primeiramente, há de se compreender que a pandemia além de se tornar um problema de saúde coletiva mundial, pode ser entendida como um sintoma social provindo de uma crise existencial e comunitária que se arrasta desde a modernidade entre os séculos XIX e XX. Para melhor compreendê-la, voltemos à Heidegger e como este aponta a contundente crise do paradigma racional nos dois últimos séculos.

Adotamos a fenomenologia-existencial de Heidegger como uma matriz epistêmico-teórica significativa do século $\mathrm{XX}$, que se contrapôs à plataforma racional, que crescentemente se postou como única forma edificante no horizonte existencial moderno. Esse modo de vida que se agudou no contemporâneo, tornou-se ainda mais decadente, porque apenas baseou-se na certeza do Cogito (pensar) e no império do método matemático e analítico. A partir da superação dessa matriz, a fenomenologia assumiu uma outra perspectiva provisória e aberta, não para substituir uma metafísica por outra, mas sim para operar um outro modo de se pensar o ser, modificando o seu agir, sentir e ressignificando o mundo. (HEIDEGGER, 2010)

Heidegger (2010) acusará a modernidade de operar um esquecimento do ser e uma entificação do mundo, ou seja, nublou no horizonte humano outras formas de pensar e agir mais abertas a sensibilidade e ao diálogo, reduzindo a complexidade ontológica e vivencial do homem à lógica material e causal. Portanto, o homem moderno esqueceu-se da sua finitude e do quanto o cuidado é essencial para se manter aliado ao mundo em que vive, afinal, somos seres-no-e-do-mundo. Esse

RBPPD/BRJPD | Vol. 2 | n. 4 | p. 4-23, 2020. 
empobrecimento foi ainda mais articulado com a hegemonia das ciências duras e naturais, a partir do século XIX, que construiu critérios rígidos e fechados de verdade, que cediam ao homem moderno uma certeza racional-instrumental, empobrecendo (outros) os modos de instalação do ser no mundo, como a arte e a religião. Enfim, algo essencial do homem se perdeu, como o pastor do ser nos convidou a pensar nesse trecho, “ hoje em dia, na verdade, o homem já não se encontra em parte alguma, consigo mesmo, isto é, com sua essência” (HEIDEGGER, 2010, p.30).

Cabral (2009), estudioso da ética heideggeriana, traduzirá essa crise como aquela provinda de uma longa história das diversas formas pelas quais o homem se pôs a compreender, explicar e descrever os seus modos de vida no mundo moderno, com o crescente imperativo da razão. Ou seja, objetificaram-se as diferentes dimensões do ente, esquecendo-se do ser e reduzindo o real a apenas uma realização da ferramenta da ratio. Cabral $(2009$, p.21) nominará esse modo de vida como raciocêntrico, marca do ocidentalismo, que o levará a uma forma infinitista de existência, na qual acreditando-se imortal, onipotente, esse homem destruirá seu próprio mundo, gerando uma crise de subsistência ecossistêmica.

Essa crise provocada pela hegemonia do modelo do raciocentrismo desembocará no mundo contemporâneo trazendo outro modo de controle e de exercer o poder micropolítico. Deleuze (2013) o nominará de Sociedade do Controle, sob organização pós panóptica, marcada por uma crise aguda de todos os meios de confinamento, da prisão à escola, com cisões graves do espaço interior. $\mathrm{O}$ autor ainda aponta que o capitalismo se reinventou, agora não é mais aquele que enfoca a produção, mas sim o mercado, difuso, imaterial e volátil. O capital mundializado tornou o homem em figura cifrada, que pode ser codificada como um produto no mercado pela sua tarja eletrônica. Somos cifras que podem consumir, sendo o marketing a nova doutrina sagrada a se seguir, pois agora as empresas passam a ter alma e invadem nossa vida privada.

RBPPD/BRJPD | Vol. 2 | n. 4 | p. 4-23, 2020. 
Chesnais (1996) afirma que a mundialização do capital ocorreu a partir da década de 80, quando extrapolou o processo de internacionalização, sob uma nova configuração do capitalismo mundializado. Esse novo momento seria demarcado por alguns mecanismos, tais como a hipercentralização de gigantescos capitais financeiros dentro do mercado, a rentabilidade associada à liquidez, a era dos administradores anônimos e dos ativos financeiros, o aumento do capital fictício, a busca frenética por credibilidade e a retroalimentação da riqueza do próprio mercado financeiro (MAIORINO, 2018).

Nessa sociedade do controle e da mundialização do capital, disseminaram-se as formas de controle micromoleculares e ondulatórios da vida social, ao ar livre, marcadas pela sua rapidez e fluidez, que passaram a substituir os mecanismos disciplinares. O controle não está mais somente nas relações verticais institucionais, mas está internalizado no eu, que passa a ser o seu próprio algoz e prisioneiro. "O controle é de curto prazo e de rotação rápida, mas também contínuo e ilimitado, ao passo que a disciplina era de longa duração, infinita e descontínua. O homem não é mais o homem confinado, mas o homem endividado" (DELEUZE, 2013, p. 228).

Deleuze (2013) apontará a existência de uma fadiga ontológica generalizada, revelada pelo cansaço de ser você mesmo, educado contínua e eficazmente, que deve se comportar como um fluxo que se reinventa a cada dia, se auto gerindo e tornando-se seu maior portfólio publicitário. Levando o homem a reproduzir a lógica dessa sociedade do cansaço, assoberbada de si mesma.

Han (2015) aponta uma sociedade além da forma disciplinar- típica da era moderna- que agora será denominada como a do desempenho, onde somos empresários de nós mesmos, focados na produtividade de si- do âmbito profissional ao pessoal - onde não há limites para o poder proativo de ser-algo. Uma sociedade com essa configuração produzirá sujeitos depressivos e fracassados, pois agora ficam a cargo de sua própria competência de sucesso/fracasso diante de uma sociedade altamente complexificada e competitiva (MAIORINO, 2018).

RBPPD/BRJPD | Vol. 2 | n. 4 | p. 4-23, 2020. 
Portanto, é sob a égide de uma sociedade consumista, neoliberal e adoecida, que a pandemia se tornou um fenômeno social, que vai além de um mecanismo biológico de alto contágio. Inúmeros pensadores do hoje têm se colocado a polemizar esse momento que vivemos, trazendo algumas contribuições para contemporizar esse cenário impensável há pouco tempo.

Numa perspectiva transversal, sob a leitura de vários pensadores do hoje, como Žižek (2020), Agamben (2020), Harvey (2020), Santos (2020) e Dunker (2020), aponta-se que essa pandemia demonstrou ser o ápice de uma crise humana, econômica e cultural, que vem se desembrulhando há tempos sob inúmeros outros sintomas de sofrimento ético político. Houve inúmeros sinais anteriores, tais como os desequilíbrios ecossistêmicos recorrentes no mundo, como as chuvas que assolaram a capital paulistana no início de 2020, o crescimento dos discursos e poderes fascistas pelo globo, entre outros.

Para Boaventura Souza Santos $\left(2020, \mathrm{~s} / \mathrm{n}^{1}\right)$, o coronavírus tem sido, para nós- homens e mulheres do século XXI- um mecanismo pedagógico cruel e desestruturante, pois ficamos esperando um novo normal, que parece desfazer-se a cada dia sob o império dos nossos sentidos. O autor aponta que esse mecanismo foi gerado intencionalmente pelo sistema de poder, naturalizando-se o impensável e realizando um estado permanente de crise, que não se resolve para "legitimar a escandalosa concentração de riqueza e impedir que tomem medidas eficazes para impedir a iminente catástrofe ecológica."

Harvey (2020) contextualiza a pandemia numa crise da espiral produtiva do capital, apontando como esse vírus causaria bloqueios e interrupções no fluxo financeiro, além de causar um processo de desvalorização generalizada de mercados econômicos e da dificuldade de se vender o que produziu a tempo. Ou seja, a pandemia veio conjuntamente com uma crise da acumulação do

1 Explicação da SIGLA S/N- Os textos de Žižek (2020), Agamben ( 2020 ), Harvey (2020), Santos ( 2020) e Dunker ( 2020) foram obtidos em formato digital na base Amazon sob a plataforma do Kindle, portanto, não consta paginação tradicional, a sigla s/n indica o "sem numeração de página", para textos com essa forma.

RBPPD/BRJPD | Vol. 2 | n. 4 | p. 4-23, 2020. 
capital, que tem sido reverberado em vários movimentos políticos em diferentes regiões do mundo, de Santiago à Beirute. "Os impactos econômicos e demográficos da propagação de um vírus dependem das fendas e vulnerabilidades preexistentes no modelo hegemônico.” (HARVEY, 2020, $\mathrm{s} / \mathrm{n})$.

Dunker (2020, s/n) caracteriza esse momento como sendo expressão de uma necropolítica generalizada, que se deu "em meio a dois processos particulares: a divisão social discursiva e a pauperização da vida econômica e dos direitos trabalhistas". Onde se inverte o princípio da biopolítica, tão estudada por Foucault: agora é fazer morrer e deixar viver.

Žižek (2020) nos alerta que esse fenômeno pandêmico reflete a crise da forma neoliberal de governar o mundo ocidental, com a hiperaceleração dos processos econômicos e produtivos, gerando a culpabilização do próprio sujeito, que se tornou tutor e empreendedor de si mesmo. Vivemos sob o império dos discursos meritocráticos e fascistas, que defendem o gozo e o poder-ser sem entraves algum. Na perversão neoliberal, a liberdade continua a ser uma ilusão, e isso fica evidente quando somos jogados dentro de um paradoxo impensável: escolher a vida ou a produtividade econômica?

Žižek (2020) afirma ainda, que o neoliberalismo criou um vírus ideológico, que provoca uma eugenia silenciosa e rápida, catalisada pelas fakes news e os racismos violentos, erguendo-se fronteiras claras e delimitando os inimigos. O Outro é sempre um possível contaminador, portanto deve-se mantê-lo afastado e eliminá-lo do convívio social.

Agamben (2020) caracteriza esse momento como hiperbiopolítico, onde se implementa propositalmente uma atmosfera de desconfiança, conspiração e pânico na população, para gerar um mecanismo de controle e apatia. Afinal, segundo o autor, vive-se uma vida nua e crua, reduzindo-a ao seu patamar o mais fisiológico possível, praticamente retratando a vida num campo de concentração e naturalizando essa condição. Ou seja, vivemos encarcerados em nossas casas e

RBPPD/BRJPD | Vol. 2 | n. 4 | p. 4-23, 2020. 
isolados em si mesmos. Com isso, o homem perde sua vitalidade e deixa de ser afetado pelo outro e pela empatia.

Diante dessa outra versão do capitalismo, caracterizado como mundializado e gravemente ferido pelo desastre do covid, vivemos ainda, um clima de pânico psicossocial, o que tem sido evidenciado pelo aumento de crises na saúde mental de boa parte da população, que se sente refém e vulnerável diante o agravo do cenário. Esse Estado de exceção parece tornar-se cada vez mais naturalizado, propiciando terreno fértil para medidas governamentais totalitárias e pouco dialogadas. Desse contexto, várias perguntas nos sobressaem, tais como: (sobre)viveremos a tudo isso? Como não perder o alcance da alteridade? Como se fazer presente na vida comunitária e afetiva do seu ao redor? Como incomodar-se e resistir aos governos despóticos e que confirmam medidas necropolíticas?

A partir dessas problematizações, o artigo buscou realizar uma analítica dos modos de presença que parecem se destacar na pandemia de 2020, por exemplo, como temos nos mostrado nas lives mantidas por aplicativos como o Instagram? Esses encontros online têm sido sustentados por diferentes temáticas e motivos, de uma simples conversa banal a um tema político. Porém esse não é um fenômeno inventado pelo contexto da pandemia do coronavírus, pelo contrário, esse modo de presença nas redes digitais, já se encontra disseminado e constitui-se como uma contundente forma de habitar o mundo contemporâneo. Para melhor entender como no ano de 2020, as lives se mostraram como um modo possível de se conviver na era pandêmica, vamos mapeá-las em terreno virtual.

\section{O INSTAGRAM COMO FENÔMENO SOCIAL DA CIBERCULTURA}

Para Costa (2002), no início do século XXI, houve uma série de transformações no campo do entretenimento e comunicação, que prometiam ao homem uma verdadeira epidemia do sem-fio,

RBPPD/BRJPD | Vol. 2 | n. 4 | p. 4-23, 2020. 
implementando uma nova cultura sincrética, que mesclava imagens, sons e publicidade. Essa cibercultura nos inundou de informações com o aparecimento e ampliação das tecnologias de informação, graças aos cabos ópticos de largo espectro, desenvolvendo novos meios de divulgação informativa. Junto a isso e acelerando ainda mais esse processo, o autor aponta a proliferação das comunidades virtuais, que implementaram um outro modo de sociabilidade e compartilhamento de tarefas e dados.

Essa cultura digital se fez num regime de captação de atenção extrema dos usuários, constituindo a era da tela-tudo, num regime de excitação dos corpos suscetíveis frente aos estímulos dessa família dessas telas e terminais. que proporcionam uma Essa hiperestimulação dos nossos campos perceptivos, promovem por sua vez, uma interatividade contínua e sedutora, onde se pode falar com qualquer um em qualquer ponto do planeta. Lemos (2004, p. 13) afirmou "estamos todos pensando na mesma rede".

Lemos (2004), inspirado por Pierre Lévy, nos ajudará a compreender como essa realidade passará a ser mais viva, inteligente e interconectada, proporcionando uma simulação interativa, onde vivemos sob outras matrizes, que não a da presença física corporal, mas de um modelo pautado pela onipresença e volátil, onde tudo se conecta e desconecta rapidamente. Como o autor nos ensina a ver:

\begin{abstract}
As novas tecnologias parecem caminhar para uma forma de onipresença, misturando-se de maneira radical e quase imperceptível ao nosso ambiente cultural através do devir micro (tornar-se invisível) e do devir estético (tornar-se belo). Esse movimento vai, como veremos, aproximar a tecnologia contemporânea do prazer estético e do compartilhamento social (LEMOS, 2004, p. 17).
\end{abstract}

Lemos (2004) aponta como esse cenário se faz entremeio a constituição de uma cibercultura, que esteve intrincada com um mundo hiperquantificado, que traduziu o real pelo uso disseminado das tecnologias digitais, ou seja, a realidade agora é pautada por uma matrix informacional. Sem

RBPPD/BRJPD | Vol. 2 | n. 4 | p. 4-23, 2020. 
dúvida, o autor aponta a importância do crescimento da microinformática desde os anos 40, com os estudos cibernéticos, sobre inteligência artificial e a telemática. Uma ciência tecnocêntrica que ditará fortemente o ritmo da vida social, transformando nosso cotidiano e a forma como nos relacionamos, inclusive uns com os outros.

A cibercultura, em meio a explosão da microinformática, segundo Lemos (2004) trará vivências ambivalentes, por um lado, acentua-se a democratização do acesso à informação, porém ao mesmo tempo, torna o sujeito uma parte sistêmica, técnica e racional de uma engrenagem muito mais complexa, desumanizando e racionalizando ainda mais o mundo ao nosso redor. Inclui e exclui-se com a mesma potência, por exemplo, agora se criam os "novos" analfabetos digitais, que não conseguem manusear as tecnologias ou mesmo filtrar as informações com qualidade. Lemos (2004) associará a cibercultura com a formação de agregados psicossociais, como podemos ler:

\begin{abstract}
A cibercultura vai se caracterizar pela formação de uma sociedade estruturada através de uma conectividade telemática generalizada, ampliando o potencial comunicativo, proporcionando a troca de informações sob as mais diversas formas, fomentando agregações sociais. O ciberespaço cria um mundo operante, interligado por ícones, portais e sítios e home pages, permitindo colocar o poder de emissão de informação nas mãos de uma cultural jovem, tribal, gregária, que vai produzir informação, agregar ruídos e colagens, jogar excesso ao sistema. (LEMOS, 2004, p. 87)
\end{abstract}

Lemos (2004, p. 81) nominará cibersocialidade, os modos de se relacionar no caldo da cibercultura, onde se colocou "a tecnologia digital contemporânea como um instrumento de novas formas de sociabilidade e de vínculos associativos e comunitários". Inspirado no filósofo francês Maffesoli, Lemos (2004) ainda descreve como esses vínculos se dão em forma de agrupamentos em torno de interesses comuns e pela atração afetiva de se estar junto, o que se nominará de proxemia cibersocial. Para Lemos, portanto, “a cibersocialidade é a sinergia entre a socialidade contemporânea e as novas tecnologias do ciberespaço" (LEMOS, 2004, p. 81), que potencializaram a habitação rápida e volátil das comunidades virtuais, atravessadas e constituídas por todas formas

RBPPD/BRJPD | Vol. 2 | n. 4 | p. 4-23, 2020. 
de agregação, do mais banal ao festivo, se reinventando em suas plataformas, da era do antigo Orkut ao Facebook.

O Instagram pertence a essa classe social das comunidades virtuais, criada por Kevin Systrom e Mike Krieger, no ano de 2010, tornando-se uma das plataformas sociais mais visitadas, com uma conta com mais de 800 milhões de usuários. De acordo com o site CanalTech(2020),

\begin{abstract}
A rede social do Instagram permite o compartilhamento de fotos e vídeos, bem como a integração com outros aplicativos. Entre as suas funcionalidades estão a aplicação de filtros, o Boomerang, os Stories, além das gravações e transmissões de vídeos ao vivo. Atualmente, o Instagram também é um dos principais veículos para a publicidade de empresas de todo o mundo. De acordo com a empresa, hoje cerca de 800 milhões de pessoas utilizam a rede social. Para dar conta do crescimento e da intensa atividade, a companhia se baseia em valores como simplicidade, criatividade e privacidade.
\end{abstract}

Pela sua importância no cenário da cibercultura e o estrondoso acesso às lives na era pandêmica, fez-se pertinente debruçar-se sobre esse cenário e compreender como os sujeitos contemporâneos têm habitado esse palco virtual.

\title{
OS MODOS DE PRESENÇA E O REGIME DE VISIBILIDADE NAS LIVES NA PANDEMIA
}

Com a ajuda da Semiótica Discursiva de cunho fenomenológico de Eric Landowski (1992; 2002), compreenderemos que o Instagram torna-se uma experiência social, a partir de um fazer de ordem cognitiva e afetiva entre atores sociais, que se fazem presentes e se estabelecem, a partir da circulação de valores e objetos de significância social, constituindo assim, um jogo intersubjetivo entre os atores sociais postos em relação.

Segundo Osman (2018), o Instagram é considerado na atualidade, uma das mais potentes ferramentas sociais, inclusive no campo do marketing digital, daí sua acessibilidade rápida e popularizada entre os jovens no Brasil, que tem se mostrado como um celeiro rico para

RBPPD/BRJPD | Vol. 2 | n. 4 | p. 4-23, 2020. 
implementadores dessas plataformas digitais. Por exemplo, Osman (2018), aponta que desde 2015, houve um aumento exponencial de $55 \%$ do uso do Instagram pelos jovens e $57 \%$ para adultos com mais de 35 anos. Tornando-se junto ao Facebook uma das maiores redes sociais no Brasil.

Para Aprobato ( 2018), o sucesso do Instagram deve-se a sua multifuncionalidade como rede social online, pois possibilita inúmeras ações entre seus usuários, do compartilhamento de fotos e vídeos, com o uso de filtros técnicos potentes, ao uso do recurso do Stories, onde o usuário pode exibir algo que lhe seja pertinente, com fotos ou vídeos, com 15 segundos de duração, que permanecem até 24 horas na conta do cibernauta.

No Brasil, do mês de abril a julho de 2020, foi muito usual a participação dos usuários nessa pólis digital do aplicativo do Instagram, que passou a acolher inúmeros eventos, nominados de Lives, que se organizaram de forma síncrona, ou seja, ao vivo, durante o período de 60 minutos, no máximo. Esses espaços se mostravam divididos topologicamente, em que se criava um verdadeiro palco e plateia a partir de uma plataforma digital, já disseminada pela cibercultura.

Para Aprobato (2018), ainda o Instagram funda conjuntamente com outras plataformas digitais um território online, que não se resume à ação de apenas estar conectado, mas sobretudo um modo de viver, ou seja, um jeito de atuar na vida, pois envolve o estilo de curtir e acompanhar o círculo de interesses do usuário diariamente. Esse hábito torna-se, segundo a estudiosa, um vínculo social, que põe em circulação diferentes valores e afetos, que por sua vez, constituem uma cartografia cultural diversificada.

Portanto, baseado primeiramente no aporte teórico da Semiótica Discursiva e nos estudos de Aprobato (2018), podemos afirmar que no Instagram, um dos valores mais em evidência colocados em circulação é a visibilidade na res pública virtualizada, ou seja, o desejo de ser visto pelo maior número de pessoas. Portanto, no Instagram encontramos práticas decorrentes da encenação de si num jogo comunicacional e interativo, onde a partir do meu mostrar-se, eu convoco o olhar do outro

RBPPD/BRJPD | Vol. 2 | n. 4 | p. 4-23, 2020. 
e mais que isso, convoco este, a "curtir" esse meu ato escópico. Então, ao mesmo tempo, eu o seduzo a se mostrar também, constituindo um mecanismo de persuasão e sedução, que não se finda apenas no meu mostrar-se, mas o de invocar o outro a realizar o mesmo ato e assim, consolidar um contrato intersubjetivo eficaz.

Portanto, baseado na teoria Landowski (1992), podemos analisar as plataformas como o de Instagram como jogos ópticos, em que se constituem situações e posições de comunicação, entre os domínios da vida privada e pública. Esses atores sociais se evidenciam dentro de um regime de visibilidade, num domínio de um campo comunicacional aberto e contaminado pela estética da publicidade. Podemos apontar que o Instagram promove uma estrutura de comunicação de função escópica, pois inspirados pela visão de Landowski sobre contratos intersubjetivos no contemporâneo, podemos realizar esse salto conceitual analítico, pois:

Como toda estrutura de comunicação, a que designa o verbo ver implica a presença de ao menos dois protagonistas unidos por uma relação de pressuposição recíproca- um que vê e o outro que é visto- e entre os quais circula o próprio objeto de comunicação, no caso a imagem que um dos sujeitos proporciona de si mesmo àquele que se encontra em posição de recebê-la (LANDOWSKI, 1992, p. 89).

Essa estrutura relacional de visibilidade necessita de uma boa condição para tornar-se visível, ou seja, tem que se garantir a presença da luz que ilumine o objeto ao olhar. Aqui no caso do Instagram, essa luz proviria da capacidade técnica da própria plataforma que fornece ao usuário (seus sujeitos escópicos), inúmeros filtros de imagem, para melhor editar as imagens compartilhadas e ainda, conta com os recursos provindos da própria tecnologia contemplada pelos dispositivos de comunicação móveis, os smartphones, cada vez mais potentes em recursos fotogênicos. Somente então esse regime de visibilidade se completa: de um lado, agora o sujeito visível tornar-se o seu próprio cenógrafo, e de outro, deve se encontrar uma cultura em que se valorize a disponibilidade do olhar; transformando o sujeito do ver, não somente em um polo

RBPPD/BRJPD | Vol. 2 | n. 4 | p. 4-23, 2020. 
receptor, mas como um captador sedento de imagens, que além de consumi-las, irá produzi-las e devolvê-las por sua vez, fechando assim o contrato intersubjetivo de natureza escópica e interativa.

Para Landowski (2002), qualquer estrutura intersubjetiva, tal como nós escolhemos estudar a desenvolvida no Instagram, envolve 3 dimensões, que também poderão ser ali visualizadas: em primeiro lugar, encontramos um regime de alteridade, onde o outro é um estranho que me coloca desnudo para poder, em seguida identificar-me com seus traços semelhantes, somente então me nomino como um EU- é a fase da identificação. Passamos à segunda dimensão, onde eu me faço existir ao outro naquele instante, é o momento da presentificação; somente então, chegamos ao terceiro domínio, onde o vislumbre de um outro distante, constitui um ele, informal, generalizável e estranho, é um ele sem rosto, que me faz pensar em ser e me mostrar a partir de algo reconhecível naquela cultura em que vivo, é a dimensão representacional.

Do ponto de vista descritivo topológico, nessa plataforma, encontramos uma tipificação usual, a tela é dividida em dois topos: no quadro acima, geralmente, o protagonista da live, o chamado anfitrião, e abaixo um convidado. Esse encontro seria ainda contemplado por uma plateia anônima, na sua maior parte, que os assistiria ansiosamente, comentando e dinamizando as conversas.

O palco das lives então fora dividido entre os dois personagens, retratando aquilo segundo Landoswki( 2002) em cenas teatrais, costuma-se nominar de uma zona de centralidade, pois ali, no palco teatral tudo tendia a convergir para si, ou seja, possui uma relativa autonomia frente aos percursos da plateia, pois se apresentara como um lugar mágico, de natureza utópica e política, pois ali aconteceria o espetáculo de um outro mundo possível. Aliás, vale aqui uma digressão, muitos episódios de lives no Instagram foram destinados a discussões de fórum político, onde os coletivos e movimentos sociais organizaram-se para habitar esse palco potente, tais como os da Mídia Ninja, o MST (Movimento sem Terra), entre outros. Tematicamente, portanto, as lives são de natureza

RBPPD/BRJPD | Vol. 2 | n. 4 | p. 4-23, 2020. 
diversa, sob a forma de palcos transformados em talkshows e encontros políticos. Além de contemplar, episódios de crítica literária ou até mesmo acústicos shows musicais. Diante dessa pluralidade temática, o Instagram consagrou-se como um espaço afetivo em que os isolados se encontravam para buscar lazer, conhecimento, puro prazer ou alienação frente ao mal estar do momento, reafirmando as impressões de Aprobato ( 2018).

Do ponto de vista figurativo das lives no Instagram, atentemo-nos para essa subdivisão topológica: acima, o espaço do anfitrião que criou o jogo escópico, como aquele que faz a tutela do tema e da disposição dialógica; na parte abaixo, o convidado, como aquele que é incluído e ao aceitar o jogo, habita o palco e faz o contrato intersubjetivo acontecer sob as luzes tecnológicas da plataforma digital. Esse espaço cênico ainda prescinde de um terceiro convidado: a plateia, onde milhares de olhares convergem para o palco da tela.

Com isso, percebe-se que o horizonte da cibercultura, que Lemos (2004) tão bem nos descreveu, tem sido um dos lugares mais privilegiados para se habitar e emanar suas marcas de presença, entre emoticons, aplausos digitais, perguntas e comentários fragmentários, esses milhares de ouvintes e receptadores das imagens e diálogos colorem esse espetáculo virtual.

As lives tornaram-se então, espaços de sociabilidade digitais, como um dos mais acessados no momento da pandemia do coronavírus. Demarcados por um modo de se fazer mostrar e ser visível complexos, em que são explorados, sobretudo os rostos em primeira dimensão, sob o pano de fundo das casas dos seus organizadores, expondo seus espaços privados. Esse parecia ser um fenômeno inusitado, nesse palco aparentemente improvisado, a vida espontânea parece ser explicitada, humanizando os atores sociais, que se mostraram entre rotinas, riqueza e a rudeza da desorganização da vida. Corpos e rostos aparecendo muitas vezes, nus, sem grandes edições fotogênicas. Enfim, será que a live tornar-se-ia o lugar da criação e da disrupção, no modo como nos tornamos visíveis?

RBPPD/BRJPD | Vol. 2 | n. 4 | p. 4-23, 2020. 
Frente a esse fenômeno inusitado, Deleuze e Guattari (2012), com seu conceito potente de Rostidade fizeram-se muito pertinentes e nos ajudaram a realizar uma última reflexão sobre esses regimes de visibilidades na vida pandêmica. Ou seja, eles podem produzir o novo ou apenas reproduzir o mesmo, sob a roupagem tecnocêntrica e imagens clichês?

Para Deleuze e Guattari (2012), a subjetivação existe sempre mediada por sistemas semióticos de significação e significantes, recheados por buracos negros, indeterminados, onde se alojam as consciências, como modos de apego e ressonâncias desses caminhos - ora desviantes ou replicantes- da experiência humana. É assim, que os pensadores franceses definem o rosto, produto de um sistema muro-branco e ao mesmo tempo, um buraco negro. "Grande rosto com bochechas brancas, rosto de giz, furado com olhos como buraco negro" (DELEUZE e GUATTARI, 2012, p. 36).

Os rostos não são individuais ou substanciais, como dita o senso comum, mas são zonas de frequência, que delimitam um campo possível de visualidade, redundantes e repletos de significações, como muros ou telas em que as impressões do mundo os atravessam. Portanto, os rostos são vagos, esburacados e obscuros, sem forma nem dimensão apriorísticas. O rosto é entendido como processo, como potência do criativo, daquilo que não se espera, como expressão da máquina abstrata da vida, podendo ser gerado segundo as combinações mais deformáveis e disruptivas, como contos de terror, nos aproximando e distanciando do que se nomina de real. Para Deleuze e Guattari (2012), portanto, os rostos concretos nascem de uma máquina chamada rostidade, que irá produzi-los à margem de qualquer expectativa fechada.

Porém, em meio ao império das tecnologias na cibercultura, repletas de sistemas massivos de reprodução de imagens, inundadas pelo mundo das telas e dispositivos que proliferam as imagens rapidamente, sob a égide da estética publicitária, não estaríamos constituindo criaturas que apenas duplicam as imagens já prontas e concretas, matando o campo de indeterminação da

RBPPD/BRJPD | Vol. 2 | n. 4 | p. 4-23, 2020. 
rostidade, como máquina do devir? Ou realizando de modo reducionista, aquilo que Deleuze e Guattari (2012) nos alertaram para não confundir, a rostidade não se dá como uma superfície com cavidade e traços límpidos. A rostidade tem muito mais relação com o rosto de que gostaríamos de ter, do que com aquele que teríamos de fato, sob a ressonância de diversos traços significantes que o mundo nos imprime.

Para os autores, portanto, o corpo assim como a cabeça em ação no mundo, serão rostificados e se mostrarão como possíveis expressões imagéticas sob diferentes contextos de exposição. Porém, quando essa rostidade é presentificada por dispositivos como o Instagram em suas lives, o que de fato assistimos? O fetichismo de um rosto pronto, preso a um modelo de corpo perfeito, submetido a mil efeitos de editores poderosos, que apagam as rugas e as imperfeições? Segundo os estudos de Aprobato (2018), sobre a replicação do ideal de juventude na cultura do curtir do Instagram, esse fetichismo é mais usual, do que poderia ser uma criação. Os usuários do Instagram parecem ser devoradores das imagens prontas disseminadas pelas celebridades. E ainda, aquilo que teria potência para romper, domestica-se e mostra apenas um retalho de uma fotografia bem montada. Originando um duplo esvaziado, sem memória, nem vida. Rostos provindos como meros reflexos límpidos da lagoa de Narciso, facialidade replicada de um perfil esperado numa caixa já formatada, onde já estão delimitados seus lugares, inclusive topológicos, pautados em imagens clichês.

Para Deleuze e Guattari (2012), esses rostos clichês, reproduzidos desde a era moderna, empobrecem o circuito de comunicação, transformando-o em uma planície conhecida e mapeada. É preciso, então, incentivar a produção daquilo que desencadeia o desvio do olhar, que reconvida ao enigma do mostrar-se, afinal, nem tudo é transparente e translúcido.

Ficaria então, a provocação, como realizar o chamamento pela disrupção desse sistema de devir homem-máquina, que parece aprisionar a grande maioria a uma facialidade produzida pelas

RBPPD/BRJPD | Vol. 2 | n. 4 | p. 4-23, 2020. 
técnicas e seus enlaces? Como provocar o ruído num sistema aparentemente perfeito e sem rugas? Esse é o desafio antropotécnico que o contemporâneo nos oferta, com toda a riqueza e complexidade que o momento oferece, entre tecnologias potentes e pavores pandêmicos.

Pensamos que devemos começar com aquilo que Foucault (2018) nos convidou a pensar, em suas conferências nos anos 80 , tornando os nossos gestos no mundo cibercultural, micropolíticos e resistentes. São ações e afetos nesse universo, que admitem a ambivalência ética e afetiva, problematizando aquilo que nos oferecem como produtos prontos e perfeitos, ou seja, duvidando do massivo e transformando a sua existência em uma obra de arte. Retomando a força do diálogo, evitando confrontos enfraquecidos por polarizações idiotizantes e reconvidando a força da pólis digital para confrontar o múltiplo e a diferença.

\section{CONSIDERAÇÕES FINAIS}

O regime de sociabilidade escópico do Instagram parece ter sido o palco escolhido na Pandemia, para trazer de um modo popularesco e afetivo, um espaço possível para os encontros, que se tornaram rarefeitos, em face do isolamento e da falta de manejo social e afetivo, que muitos países mostraram não ter, devido ao inusitado e o (im)previsível. Compreendemos, pela leitura caleidoscópica de diferentes pensadores, que a pandemia tem sua face sociocultural, expressão de uma crise do racioncentrismo que se arrasta por séculos. Funcionando como um chamamento coletivo grave que nos faz repensar o modo de organizar o coletivo e o espaço do diálogo num mundo cibercultural.

Com inspiração teórica da Semiótica francesa, de linhagem pós estruturalista e fenomenológica de Eric Landowski ( 2002) e os estudos de Aprobato (2018), compreendemos que o Instagram constitui uma estrutura de comunicação baseada num regime de visibilidade complexo, onde os sujeitos envolvidos desenvolvem diferentes competências: ser visto, ser bem iluminado e

RBPPD/BRJPD | Vol. 2 | n. 4 | p. 4-23, 2020. 
cenografado, o poder-ver e se dispor a ver sempre o outro. Portanto, afirmamos que o modo de presença no Instagram se dá dentro desse esquema intersubjetivo e escópico, funcionando como um regime de presença cênico e situacional.

Essas três dimensões podem ser localizadas no regime de visibilidade do Instagram, ei-lo: minha forma de presença se dá, não somente frente aquele que eu adoto como amigo/conhecido e que curti meus posts imagéticos, mas ao me presentificar frente a esse Outro já identificável, eu também estou ao mesmo tempo, buscando uma representação adequada ao jogo cultural que participo, onde o palco é maior e fosco, pois é ali onde busco os valores da sociedade e cultura a que pertenço, que me incentivam a me mostrar de um modo assimilável a tudo que vejo e apreendo.

Frente a esse regime de visibilidade nas lives do Instagram se implementam, hegemonicamente, imagens clichês, que podem nos aprisionar em caixas prontas de discursos e modos de se ver e se mostrar, replicando modelos prontos, dados pelas celebridades. É preciso reconvidar o gesto dialógico e afetivo, a confrontar-se, sem polaridades emburrecidas e divertir-se com a diferença, utilizando inclusive do ciberespaço para o exercício afetivo dessa vida micropolítica.

\section{REFERÊNCIAS}

APROBATO, V. C. Corpo digital e bem estar na rede Instagram: um estudo sobre as subjetividades e afetos na atualidade. Bol. - Acad. Paul. Psicol., São Paulo, v. 38, n. 95, p. 157-164, 2018 . Disponível em: $<$ http://pepsic.bvsalud.org/scielo.php?script=sci_arttext\&pid=S1415-711X2018000200003\&lng $=$ pt\&nrm=iso $>$. Acesso em: 17 dez. 2020.

AGAMBEN, G. Reflexões sobre a peste: Ensaios em tempos de pandemia. São Paulo: Ed Boitempo, 2020.

BOAVENTURA, S. A Cruel pedagogia do vírus. São Paulo: Ed Boitempo, 2020.

RBPPD/BRJPD | Vol. 2 | n. 4 | p. 4-23, 2020. 
CABRAL, A. Heidegger e a destruição da ética. Rio de Janeiro: Ed. UFRJ, 2009.

CANAL TECH .Tudo sobre o Instagram. Disponível em: <

https://canaltech.com.br/empresa/instagram/\#: :text=O\%20Instagram $\% 20$ foi $\% 20$ criado\%20por,mai s\%20promissores $\% 20 \mathrm{da} \% 20 \mathrm{App} \% 20$ Store.\&text $=$ De $\% 20$ acordo $\% 20$ com $\% 20 \mathrm{a} \% 20$ empresa,pessoa s\%20utilizam\%20a\%20rede\%20social.> Acesso em: 14 de novembro 2020.

CHESNAIS, F. A Mundialização do Capital. São Paulo: Ed Xamã, 1996.

COSTA, R. A cultura digital. São Paulo: Ed Publifolha, 2002.

DELEUZE, G. Conversações. São Paulo: Ed 34, 2013.

DELEUZE, G.; GUATTARI, F. Mil platôs: capitalismo e esquizofrenia, vol 3. São Paulo: Ed 34, 2012.

DUNKER, C. A arte da quarentena para principiantes. São Paulo: Ed. Boitempo, 2020.

FOUCAUlT, M. Microfísica do Poder. Rio de Janeiro: Ed Paz e Terra, 2018.

HAN, B. Sociedade do Cansaço. São Paulo: Ed Vozes, 2015.

HARVEY, D. Anticapitalismo em tempos de pandemia: marxismo e ação coletiva. São Paulo: Ed Boitempo, 2020.

HEIDEGGER, M. Ensaios e Conferências. São Paulo: Ed Vozes, 2010.

LANDOWSKI, E. Presenças do outro. São Paulo: Ed Persectiva, 2002.

LANDOWSKI, E. A Sociedade Refletida. São Paulo: Ed EDUC, 1992.

LEMOS, A. Cibercultura: tecnologia e vida social na cultura contemporânea. Porto Alegre: Ed Sulinas, 2004.

MAIORINO, F. O contemporâneo através do cinema: o olhar distópico, o ilusório e o trágico. 2018. Tese (Doutorado). Faculdade de Educação, Universidade de São Paulo, São Paulo, 2018.

OSMAN, M. Stagram Stats Every Marketer Should Know for 2018. Spoutsocial. 2018. Disponível em: <http://sproudsocial.com/insights/instagram-stats $>$. Acesso em: 10 de dezembro de 2020.

ŽIŽEK, S. Pandemia: COVID 19 e a reinvenção do comunismo. São Paulo: Ed Boitempo, 2020.

RBPPD/BRJPD | Vol. 2 | n. 4 | p. 4-23, 2020. 